\title{
Anodic oxidation of cefaclor antibiotic in aqueous solution containing potassium chloride
}

\section{Kurt A.*}

Central Research Laboratory for the Scientific and Technological Supports, Duzce University, Konuralp Campus, 81620, Duzce, Turkey Received: 24/12/2019, Accepted: 11/08/2020, Available online: 22/09/2020

*to whom all correspondence should be addressed: e-mail: kurtayse1987@gmail.com https://doi.org/10.30955/gnj.003267

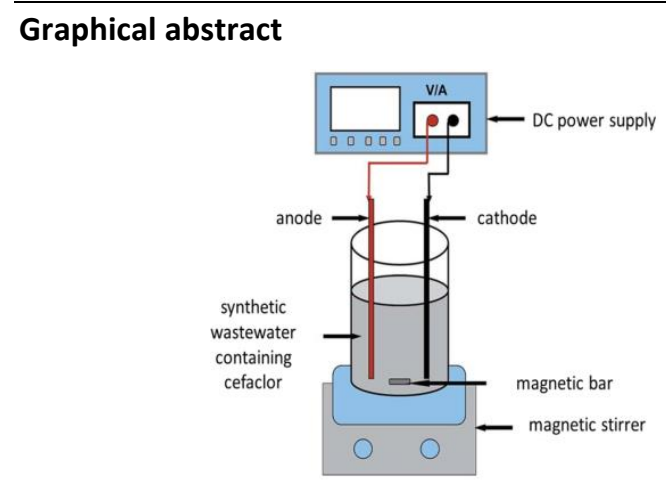

\section{Abstract}

At this study, electrochemical oxidation of cefaclor antibiotic was investigated with new generation $\mathrm{Sn} / \mathrm{Sb} / \mathrm{Ni}$ $\mathrm{Ti}$ anodes. Platinized titanium was used as cathode material. Chemical oxygen demand (COD), total organic carbon (TOC) and cefaclor (CEF) active substance parameters were used to evaluate the process efficiency. Salt $(\mathrm{KCl})$ addition $\left(\mathrm{mg} \mathrm{L}^{-1}\right), \mathrm{pH}$ value, current density ( $\mathrm{mA}$ $\mathrm{cm}^{-2}$ ) and reaction time (minute) were the factors controlling the reactions. Kinetic evaluations were performed during the application of electrochemical oxidation processes to obtain pseudo-first degree kinetics. $750 \mathrm{mg} \mathrm{L}^{-1} \mathrm{KCl}, \mathrm{pH} 7$ and $50 \mathrm{~mA} \mathrm{~cm}^{-2}$ current density were found as the optimum conditions at room temperature (25 $\left.{ }^{\circ} \mathrm{C}\right)$. Thus, $\leq \% 99$ removal efficiencies were found for COD and TOC parameters after 60 min reaction and complete mineralization of CEF was occured in just $30 \mathrm{~min}$ at the optimum conditions. Consequently, $\mathrm{Sn} / \mathrm{Sb} / \mathrm{Ni}-\mathrm{Ti}$ anodes were found very useful and successful for cefaclor oxidation and mineralization. The advantages of the processes are complete mineralization at shorter reaction time with low current densities and there is no need to $\mathrm{pH}$ arrangement.

Keywords: Antibiotic, cephalosporin, cefaclor, degradation, electrochemical oxidation.

\section{Introduction}

For toxicologic properties, causing to the microorganism resistance and contamination problems in the environment, antibiotics should be considered as the most dangerous pollutant types (Yonar and Kurt, 2017). Due to interrupting biosynthesis of bacterial cell wall, bacteria show cross-resistance to the antibiotics (Baron, 1996). Among these antibiotic groups, cephalosporin antibiotics belong to the $\beta$-lactam group, are present the most commonly in the aquatic environment, which are especially used in human and veterinary processes (Kümmerer, 2009; Harris et al., 2012; Ribeiro et al., 2018).

In worldwide, production of cephalosporin antibiotics increases constantly due to increasing demand in the sanitation (Harris et al., 2012). Most of the researchers focused on fluoroquinolone, trimethoprim, sulfonamide and macrolide antibiotics for the occurrence and fate of antibiotics and the removal technologies in various types of wastewater containing antibiotics, while, just a little of them investigated the cephalosporin antibiotics (Gros et al., 2013; Stackelberg et al., 2004; Zhou et al., 2013; Yao et al., 2015).

Cefaclor is a b-lactam group antibiotic belongs to the cephalosporin, widely used for treatment of microbial infections (pneumonia and ear, lung, skin, throat and urinary tract infections) causing by gram-positive and gram-negative bacteria (Joshi, 2002). Also, cefaclor is one of the most common used antibiotics in many of the countries worldwide for producing and prescribing. It has been seen that, it could be detected in sewage treatment plants $\left(1 \leq \mu \mathrm{g} \mathrm{L}^{-1}\right)$ (Khan and Ongerth, 2002; Park, 2006). It has a fundamental structure such as the penicillin. In Figure 1. it was stated the chemical structure of cefaclor antibiotic.

Antibiotics reach to the aquatic environment without adequate treatment in conventional treatment plants (Kümmerer, 2009; Khetan and Collins, 2007). According to the Khetan and Collins (2007), it was obtained low degradation rates of antibiotic compounds after biological and photochemical processes and hydrolysis of wastewaters. For treatability of wastewaters containing antibiotics, advanced treatment technologies are suggested, such as advanced oxidation processes (AOPs), modern pressure-driven membrane processes and reverse osmosis or nanofiltration (NF/RO) (Kosutic, 2007; Kurt and 
Yonar, 2017). Among these processes advanced oxidation processes (AOPs) are successful for providing complete mineralization and constant energy need due to the using of direct current. However, these processes need higher energy compared to the electrochemical oxidation processes which are the other types of AOPs (Christensen et al., 2009). However, electrochemical oxidation processes show the conversion of pollutants to the harmless end products and need lower energy due to the use of direct current and need less additional chemicals (Moura et al., 2014).

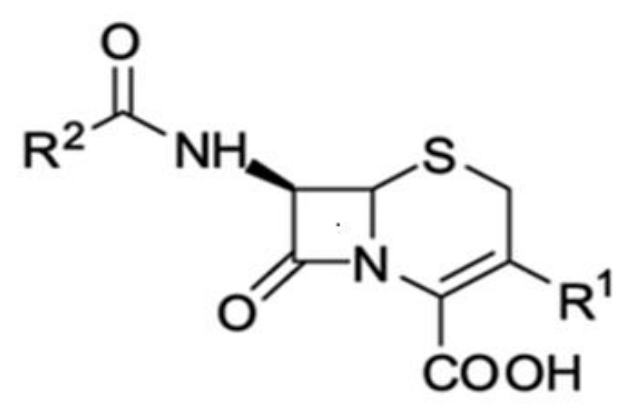

$$
\text { Cefaclor : } \mathrm{R}^{1}=\mathrm{Cl}, \mathrm{R}^{2}=\mathrm{CHNH}_{2}
$$

Figure 1. Chemical structure of cefaclor

The main disadvantageous of the various anodic materials tested on electrochemial oxidation of organic pollutants are: rapid surface fouling and contain only selectively oxidized pollutants (Polcaro et al., 1999). $\mathrm{PbO}_{2}$ (Polcaro et al., 1999; Samet et al., 2006), $\mathrm{SnO}_{2}$ (Samet et al., 2006; Comninellis and Battisti, 1996), and BDD (Panizza and Cerisola, 2005) anodes have shorter lifetime and higher costs (Correa-Lozano et al., 1997). Sn/Sb/Ni-Ti anodes are known with their stability and performance in electrochemical processes. The most important advantage of this anode is need lower voltage (Christensen et al., 2009).

However, there is almost no study on electrochemical oxidation of wastewaters containing antibiotics with new generation $\mathrm{Sn} / \mathrm{Sb} / \mathrm{Ni}$-Ti anodes in literature. They are more advantageous in terms of cost and application than BDD (boron doped diamond) anodes which are commonly used for electrochemical oxidation of wastewaters. For these reasons in this study, it was investigated electrochemical oxidation of cefaclor antibiotic with new generation $\mathrm{Sn} / \mathrm{Sb} / \mathrm{Ni}-\mathrm{Ti}$ anodes (37\% current efficiency) (Abbasi et al., 2014). The effects of reaction parameters were evaluated and kinetic evaluation and anode characterization were performed to evaluate of the electrochemical oxidation of CEF. There is no such studies on treatment of antibiotics with these anodes made this study unique.

\section{Materials and methods}

\subsection{Chemicals and synthetic wastewater preparation}

For preparation of the synthetic wastewater containing cefaclor was prepared with ultrapure water (Millipore Milli$\mathrm{Q}, 18 \mathrm{M} \Omega \mathrm{cm}$ ). The concentration of the CEF in synthetic wastewater was arranged to be $50 \mathrm{mg} \mathrm{L}^{-1}$. Cefaclor active substance was supplied from a local pharmaceutical warehouse (Duzce, Turkey). $\mathrm{SnCl}_{4} .5 \mathrm{H}_{2} \mathrm{O}$ (tin IV chloride pentahydrate) and $\mathrm{NiO}$ (nickel II oxide) were bought from Alfa Aeser Company (Massachusetts, USA) and $\mathrm{Sb}_{2} \mathrm{O}_{3}$ (Antimony III oxide) was purchased from Merck (Darmstadt, Germany) which were used for the coating processes of the anode. The other chemical solutions used during the experiments; $\mathrm{HCl}$ (hydrochloric acid), $\mathrm{H}_{2} \mathrm{SO}_{4}$ (sulphuric acid), $\mathrm{C}_{2} \mathrm{H}_{2} \mathrm{O}_{4}$ (oxalic acid) and $\mathrm{C}_{2} \mathrm{H}_{5} \mathrm{OH}$ (ethanol) were purchased from Merck (Darmstadt, Germany). The purity of all the chemicals were $\geq 99$.

\subsection{Design of the electrodes and reactor}

Titanium anodes $(2,5 \mathrm{~cm} \times 2,5 \mathrm{~cm})$ and platinized titanium cathodes $(5 \mathrm{~cm} \times 5 \mathrm{~cm})$ were used for the electrochemical reactions. Cathodes were purchased from NRK Electrochem. (Cornwall, UK). For design of the $\mathrm{Sn} / \mathrm{Sn} / \mathrm{Ni}-\mathrm{Ti}$ anodes, titanium meshes (Dexmet, USA) were immersed into the boiling solution with oxalic acid $\left(\mathrm{C}_{2} \mathrm{H}_{2} \mathrm{O}_{4}, \% 10\right)$ to remove the impurities. For coating process, Ti meshes were treated using ultrasonic process for 3 times, each phase was arranged to be 10 minutes. Then the meshes were coated by pyrolis for $2 \mathrm{~min}$, in solution having molar rate: $\mathrm{Sn} / \mathrm{Sb} / \mathrm{Ni}$ : 500/8/1. Finally, they were incubated at $105^{\circ} \mathrm{C}$ in the etuv that preheated for $15 \mathrm{~min}$. Then it was repeated for $520{ }^{\circ} \mathrm{C}$ temperature for $15 \mathrm{~min}$. The cycle of coating process was repeated for 15 times and at the last stage, process was repeated for $75 \mathrm{~min}$ (Christensen et al., 2013; Wang et al., 2015).

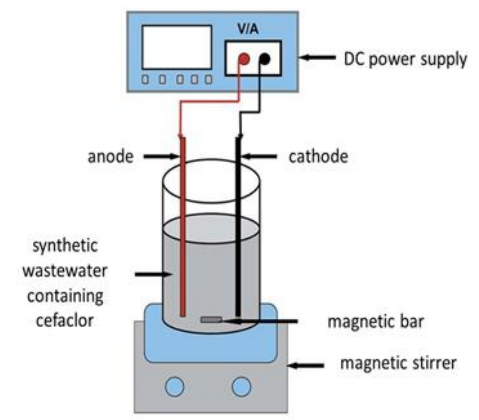

Figure 2. Configuration of electrochemical reactor

To perform the electrochemical reactions, $250 \mathrm{~mL}$ borosilicate glass beakers were used. The anode and cathode were placed inside the reactor mutually. In Figure 2 it is seen the configuration of electrochemical reactor with electrodes (anode\&cathode).

Anode material (the most important parameter affecting the reactions, should be strong enough to ensure polarization), reactor configuration, current efficiency, $\mathrm{pH}$, salt type and conc. affects directly electrochemical oxidation (Cui et al., 2009). Organic molecules could be oxidized by direct or indirect electrochemical oxidation reactions. Low potential values are reccommended for direct electrochemical oxidation of wastewater containing organics (Carlos and Sergio, 2006; Simond et al., 1997). In equation 1 it was stated the transformation of water to oxygen before direct electrochemical oxidation reaction occur with ${ }^{\circ} \mathrm{OH}$ radicals (equation 1 ). 


$$
2 \mathrm{H}_{2} \mathrm{O} \rightarrow \mathrm{O}_{2}+4 \mathrm{H}^{+}+4 \mathrm{e}^{-} \quad\left(\mathrm{E}^{\circ}: 1,23 \mathrm{~V}\right)
$$

Occurring of ${ }^{\circ} \mathrm{OH}$ radicals at anode by oxidation of water was shown in equation 2.

$$
\mathrm{H}_{2} \mathrm{O} \rightarrow{ }^{\cdot} \mathrm{OH}_{\mathrm{ads}}+\mathrm{H}^{+}+\mathrm{e}^{-}
$$

At indirect electrochemical oxidation reactions various oxidant types may occur such as chlorine, hypochlorous acid/hypochlorite, hydrogen peroxide and ozone (Bergmann et al., 2014):

$$
\begin{aligned}
& 2 \mathrm{Cl}^{-} \rightarrow \mathrm{Cl}_{2}+2 \mathrm{e}^{-} \\
& \mathrm{Cl}_{2}+\mathrm{H}_{2} \mathrm{O} \rightarrow \mathrm{HOCl}+\mathrm{H}^{+}+\mathrm{Cl}^{-} \\
& \mathrm{HOCl} \rightarrow \mathrm{H}^{+}+\mathrm{OCl}^{-} \\
& \mathrm{Cl}^{-} \rightarrow \mathrm{Cl}^{-} \mathrm{e}^{-} \\
& \mathrm{Cl}^{-}+\mathrm{OH} \rightarrow \mathrm{Cl}+\mathrm{OH}^{-} \\
& \mathrm{OH}^{-} \rightarrow \mathrm{OH}^{+} \mathrm{e}^{-} \\
& \mathrm{H}_{2} \mathrm{O} \rightarrow \mathrm{OH}^{+} \mathrm{H}^{+}+\mathrm{e}^{-} \\
& 2 \cdot \mathrm{OH} \rightarrow \mathrm{H}_{2} \mathrm{O}_{2} \\
& \mathrm{H}_{2} \mathrm{O}_{2} \rightarrow \mathrm{O}_{2}+2 \mathrm{H}^{+}+2 \mathrm{e}^{-} \\
& \mathrm{O}_{2}+\mathrm{O} \rightarrow \mathrm{O}_{3}
\end{aligned}
$$

\subsection{Analytic studies}

Total organic carbon (TOC) analysis of the wastewater samples were carried out with TOC analyser (TOC-L, Shimadzu, Japan). pH meter (Cyberscan, UK) was used for measure of the $\mathrm{pH}$ values. Ultra performanced liquid chromatography (UPLC) with photo diode array detector (PDA) (Thermo-scientific, Massachusetts, USA) was used for analytic analysis of cefaclor, at 254 and $270 \mathrm{~nm}$ wavelengths for detector. Hypersil GOLD, C-18 (50 x 2,1 $\mathrm{mm} ; 1,9$ um) UPLC column (Thermo-scientific, Massachusetts, USA) was used for the processes. Temperature of the column was chosen as $35^{\circ} \mathrm{C}$.

The mobile phase content was set as $0,1 \%$ formic acid and methanol; [MeOH: $\left.\mathrm{H}_{2} \mathrm{O}\right]: 40: 60(\mathrm{v} / \mathrm{v})$ ] and 0,2 $\mathrm{mL} \mathrm{min}^{-1}$ flow rate was arranged at UPLC process. Chemical oxygen demand (COD) measurements were carried out according to the Standard Methods (APHA, 1989). All of the measurements were carried out in triplicate.

\subsection{Kinetic studies}

To determine the pseudo-first-degree kinetics of the electrochemical degradation of CEF, kinetic coefficient was determined from the slope of the curve formed according to the equation (13);

$$
\ln \left(\mathrm{C}_{(\mathrm{CEF})} / \mathrm{C}_{(\mathrm{CEF}) \mathrm{O}}\right): \mathrm{kd} \times \mathrm{t}
$$

\section{Results and discussion}

\subsection{Effect of salt type and concentration}

New generation $\mathrm{Ti}$ doped $\mathrm{Sn} / \mathrm{Sb} / \mathrm{Ni}$ anodes are known for high capacity of ozone generation. According to the most of the studies, it was seen that, type and dose of electrolyte $(\mathrm{NaCl}, \mathrm{KCl})$ affected positively the electrochemical oxidation reactions by increasing conductivity (Comninellis and Battisti, 1996; Abbasi et al., 2014; Christensen et al., 2013; Wang et al., 2015). Also, when salt is added for the process, chloride gas occurs too much thus, hypochlorid acid, that are very good oxidants (Parsa and Abbasi, 2012; Sasidharan and Gupta, 2016). But the addition of extra salt may increase the cost and create risks for the environment.
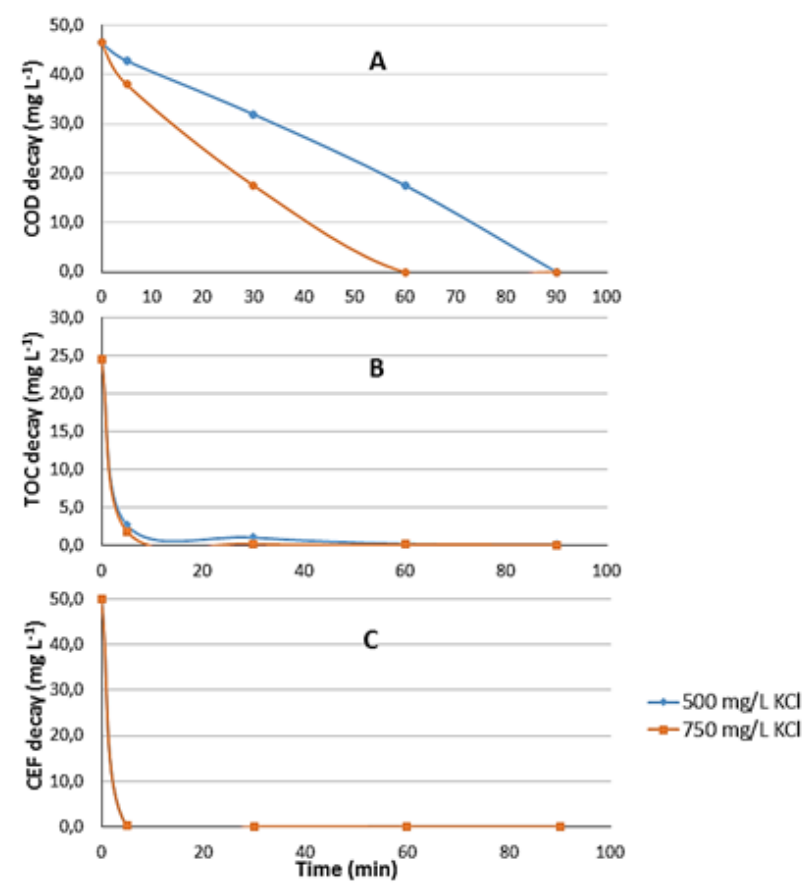

Figure 3. Effect of $\mathrm{KCl}$ on process parameters (I: $50 \mathrm{~mA} \mathrm{~cm}^{-2}, \mathrm{pH}$ 7), (a) COD decay ( $\mathrm{mg} \mathrm{L}^{-1}$ ), (b) TOC decay (mg L $\mathrm{L}^{-1}$ ), (c) CEF decay (mg L-1)

In salt addition processes with $\mathrm{KCl}$, it was obtained that $\mathrm{KCl}$ affected the process efficiencies more positively even in lower concenrations. Thus, first of all in this study, effect of $\mathrm{KCl}$ (potassium chloride) on control parameters; COD, TOC and CEF were evaluated for 500 and $750 \mathrm{mg} \mathrm{L}^{-1} \mathrm{KCl}$, at $\mathrm{pH} 7$ and $50 \mathrm{~mA} \mathrm{~cm}^{-2}$ current density. The effect of $\mathrm{KCl}$ addition on result parameters was shown in Figure 3. According to the Figure 3, it was seen that TOC and CEF decays showed similar trends in a very short time. However, COD reduction was much clearer as a conventional parameter, thus, it was considered and evaluated as a major parameter in our study. Due to the lower voltage, it couldn't obtain higher efficiencies at $500 \mathrm{mg} \mathrm{L}^{-1} \mathrm{KCl}$, thus the optimum dose was found as $750 \mathrm{mg} \mathrm{L}^{-1}$ providing the higher removal efficiencies at shorter times. 


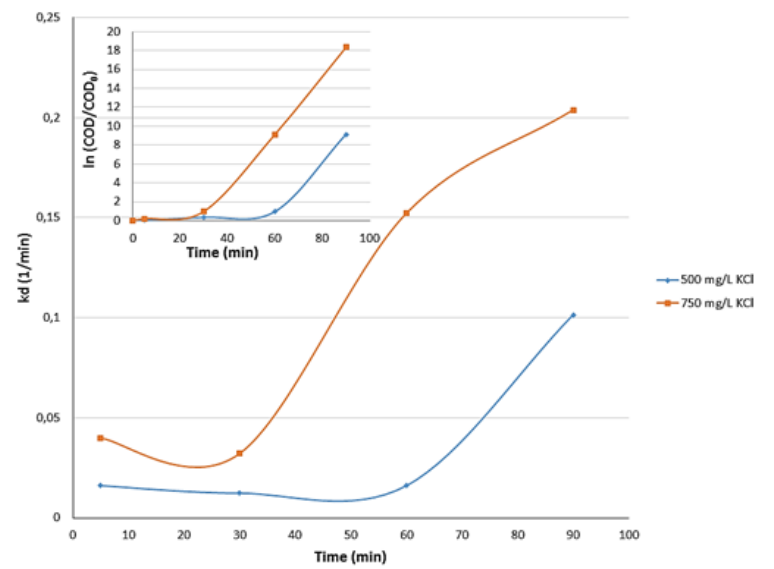

Figure 4. Pseudo-first order kinetics with $\mathrm{KCl}$ variation (I: $50 \mathrm{~mA}$ $\mathrm{cm}^{-2}$ and $\mathrm{pH}$ 7)

According to the Figure 3, COD was consumed in just 60 minutes with $750 \mathrm{mg} \mathrm{L}^{-1} \mathrm{KCl}$ addition. TOC was reduced to $0,20 \mathrm{mg} \mathrm{L}^{-1}$ just after $30 \mathrm{~min}$ reaction and $0,06 \mathrm{mg} \mathrm{L}^{-1}$ after 90 minutes and CEF concentration was consumed in $30 \mathrm{~min}$ reaction with $750 \mathrm{mg} \mathrm{L}^{-1} \mathrm{KCl}$.

However, pseudo-first order removal rate constants $\left(k_{d}\right)$ were calculated for $\mathrm{KCl}$ addition, to obtain clearer results. According to the Figure 4, with $k_{d}$ coefficients it was obtained that $\mathrm{KCl}$ affected the electrochemical reactions considerably, due to increase of conductivity and chloride gas formation and thus, hypochlorid acid.

However, the advantage of using $\mathrm{KCl}$ as a salt type is to reduce the negative effects of $\mathrm{NaCl}$ on soil structure. When $\mathrm{NaCl}$ is used as a salt additive, soil pore size and water permeability is reduced due to adsorption of $\mathrm{Na}^{+}$to negatively charged clay surfaces and it could be replaced with other ions (Tchobanoglous and Schroeder, 1985).

\subsection{Effect of $p H$}

The effect of $\mathrm{pH}$ was investigated at the range of (Gros et al., 2013; Joshi, 2002; Harris et al., 2012; Kümmerer, 2009; Ribeiro et al., 2018; Stackelberg et al., 2004; Yao et al., 2015; Zhou et al., 2013), on COD, TOC, and CEF decay, which is one of the most important parameter affecting the electrochemical oxidation reactions. Thus, the optimum $\mathrm{pH}$ was obtained after the electrolyte concentration.

Figure 5 shows the effect of $\mathrm{pH}$ on the result parameters for $750 \mathrm{mg} \mathrm{L}^{-1} \mathrm{KCl}$ addition and $50 \mathrm{~mA} \mathrm{~cm}^{-2}$ current density. According to the Figure 5 and Figure $6, \mathrm{pH} 7$ was found as the optimum value for electrochemical oxidation of $\mathrm{CEF}$, which is the neutral $\mathrm{pH}$ of the wastewater. Also, it is possible to make process more economic and easier operationally, by working at neutral $\mathrm{pH}$, due to there is no need extra $\mathrm{pH}$ arrangement steps. According to the Figure 4, COD was consumed just after $60 \mathrm{~min}$ and TOC was mineralized almost completely after $30 \mathrm{~min}$ and CEF conc. was reached to the zero just in $5 \mathrm{~min}$, at $\mathrm{pH} 7$.
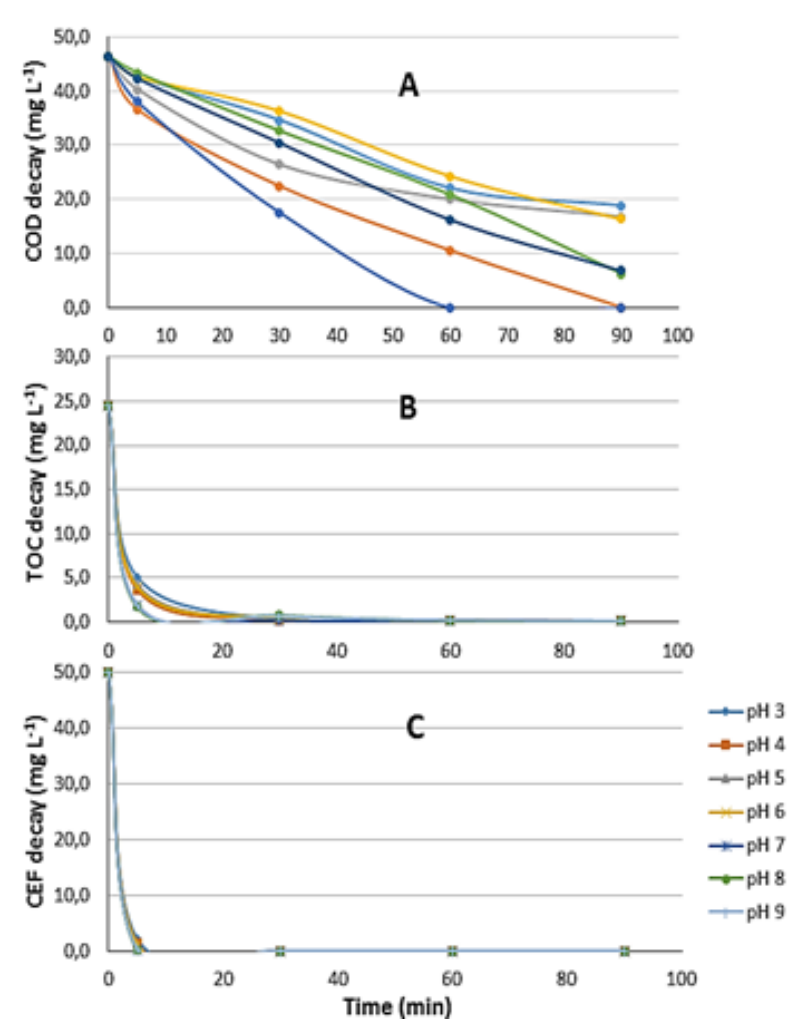

Figure 5. Effect of $\mathrm{pH}$ on process parameters $\left(\mathrm{KCl}: 750 \mathrm{mg} \mathrm{L}^{-1}\right.$, I: $50 \mathrm{~mA} \mathrm{~cm}{ }^{-2}$ ), (a) COD decay ( $\left.\mathrm{mg} \mathrm{L}^{-1}\right)$, (b) TOC decay ( $\left.\mathrm{mg} \mathrm{L}^{-1}\right)$, (c) CEF decay $\left(\mathrm{mg} \mathrm{L}^{-1}\right)$

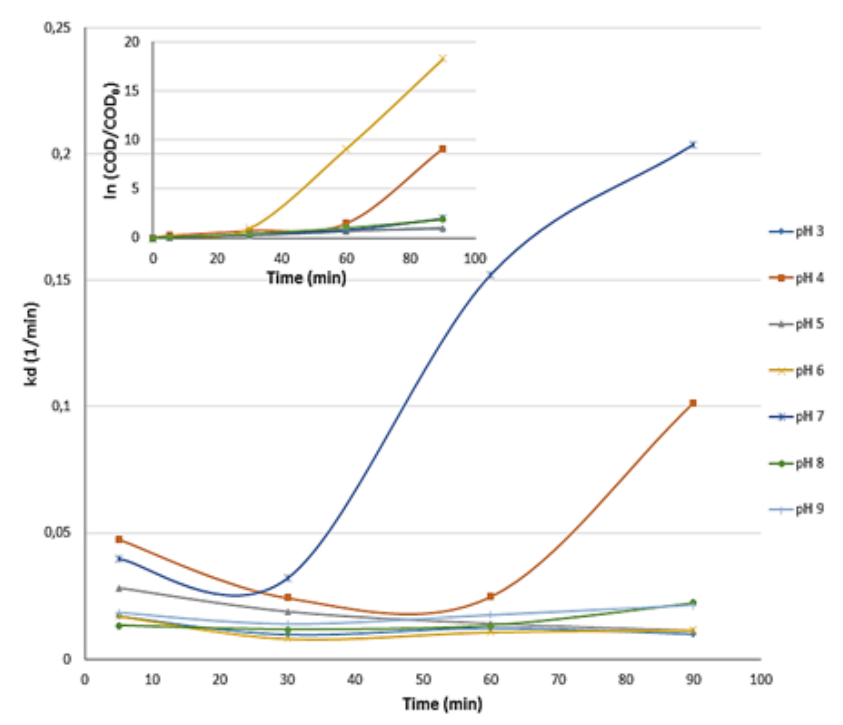

Figure 6. Pseudo-first order kinetics with $\mathrm{pH}$ variation ( $\mathrm{KCl}: 750$ $\mathrm{mg} \mathrm{L}^{-1}, \mathrm{I}: 50 \mathrm{~mA} \mathrm{~cm}^{-2}$ )

\subsection{Effect of current density}

In electrochemical oxidation processes, current density is another parameter, affecting the reactions significantly having an active role in reaction kinetics (Deng and Englehardt, 2007). At the range of $25-50 \mathrm{~mA} \mathrm{~cm}^{-2}$, effects of current density were evaluated for $750 \mathrm{mg} \mathrm{L}^{-1} \mathrm{KCl}$ addition and $\mathrm{pH} 7$. 

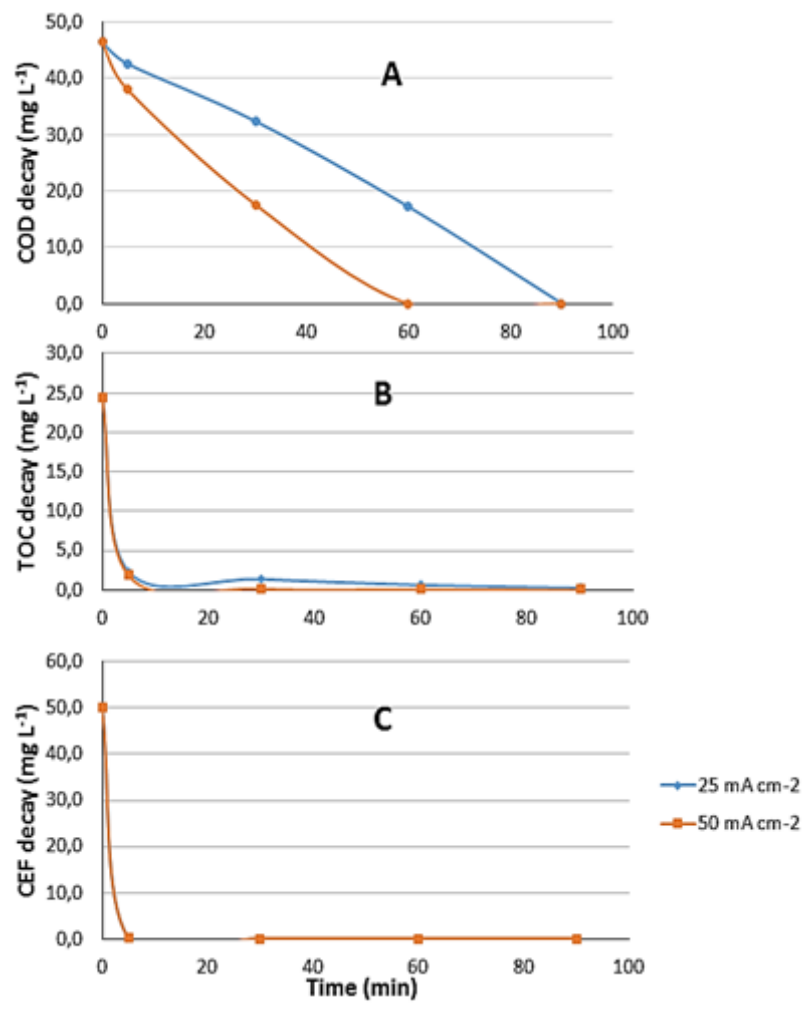

Figure 7. Effect of current density on process parameters ( $\mathrm{KCl}$ : $750 \mathrm{mg} \mathrm{L}^{-1}, \mathrm{pH}$ 7), (a) COD decay (mg L-1), (b) TOC decay (mg L-1), (c) CEF decay (mg L-1)

Active oxidants occur increasingly in aqueous solution at higher current density values. Thus, the removal efficiencies increased generally with the current density increase. Optimum current density was found as $50 \mathrm{~mA} \mathrm{~cm}^{-2}$, providing the most efficient treatment process (full mineralization was obtained at just $60 \mathrm{~min}$ ).

Figures 7 and 8 show the effect of current density on process parameters. According to these figures, variation in current density values affected the reactions highly. The COD was consumed completely in just 60 min oxidation, TOC was reduced to $0,20 \mathrm{mg} \mathrm{L}^{-1}$ in $30 \mathrm{~min}$ and CEF was almost consumed completely in just $5 \mathrm{~min}$ at $\mathrm{pH} 7$.

To identify the differences exactly, $k_{d}$ values were calculated for COD decay differences on current density values and parallel results were found with the others (Figure 8).

\section{Cost analysis}

Cost analysis of the study was performed according to the energy consumption rates during the electrochemical oxidation process (other labor costs are not included). The cost of the anodic oxidation process was found to be 22,75 USD/kgCOD. When compared to other conventional treatment processes, less oxidation time and no sludge occurance are the advantageous of this process in addition to the cost efficiency. According to the cost analysis, electrochemical processes with new generation $\mathrm{Sn} / \mathrm{Sb} / \mathrm{Ni}$ $\mathrm{Ti}$ anodes, showed promising results for future processes.

Energy consumption per unit COD removal; ECOD was calculated according to the Equation 14.

$$
\mathrm{E}_{\mathrm{COD}}=\left(\mathrm{E}_{\text {cell }} \times \mathrm{I} \times \mathrm{t}\right) /(\mathrm{V} \times \Delta \mathrm{COD})
$$

ECOD: energy consumption, $\mathrm{kWh} \mathrm{kg}^{-1} \mathrm{COD}$,

Ecell: electrochemical cell voltage, volt,

I: current value, ampere,

$\mathrm{t}$ : time of electrolysis, hours,

$\mathrm{V}$ : cell volume, $\mathrm{L}$ and

$\triangle C O D$ : COD removal conc., start - finishing time.

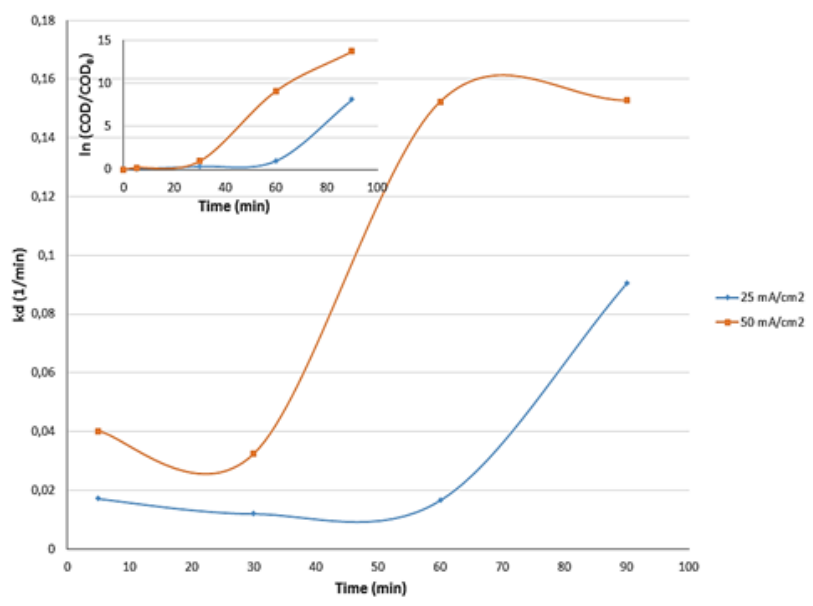

Figure 8. Pseudo-first order kinetics with current density variation ( $\mathrm{KCl}: 750 \mathrm{mg} \mathrm{L}^{-1}, \mathrm{pH}$ 7)

As it is seen in Figure 8, higher current densities increased the power consumption, while the removal efficiencies were increased. According to the Figure 9, a dramatic increase in energy consumption was occured with increasing current densities.

\section{SEM-EDS analyzes}

Typical SEM images of the anodes on the intersections (assuming thicker coating have been than the strands) (Christensen et al., 2013) were shown in Figure 10 and 11 for unused (clean) and used (unclean) anodes, respectively at $\times 250$ magnification. A cracked morphology was observed for the coating process for unused anodes that could be occurred by thermal shocking which is seen generally during the cooling process with suddenly taking of the anodes from the oven (Parsa and Abbasi, 2012; Shekarchizade and Amini, 2011; Montilla et al., 2004). However for the unclean (used) anodes, a smoother surface was observed that resulting from the coating of the surface area with ions that passing from the solution.

Thus, this state was supported by EDS spectra (Figure 12) and the weight and atomic percentages and peak intensities (Figure 12). According to the results of the analysis, it was observed that the weight and atomic percentages and the peak intensities were changed by the selected areas (area-1, area-2 and area-3) during the electrochemical oxidation processes. It was seen that the surface of the electrode was filled with other ions (carbon) and salts $\left(\mathrm{Fe}_{3}\left(\mathrm{PO}_{4}\right)_{2}(\mathrm{OH})_{2}\right)$ occurring in the solution, especially for the area-2 and area-3, assuming a smoother surface and considering the weight and atomic 
percentages and the peak intensities variation. Moreover, the anode material was not corroded significantly and worked efficiently.

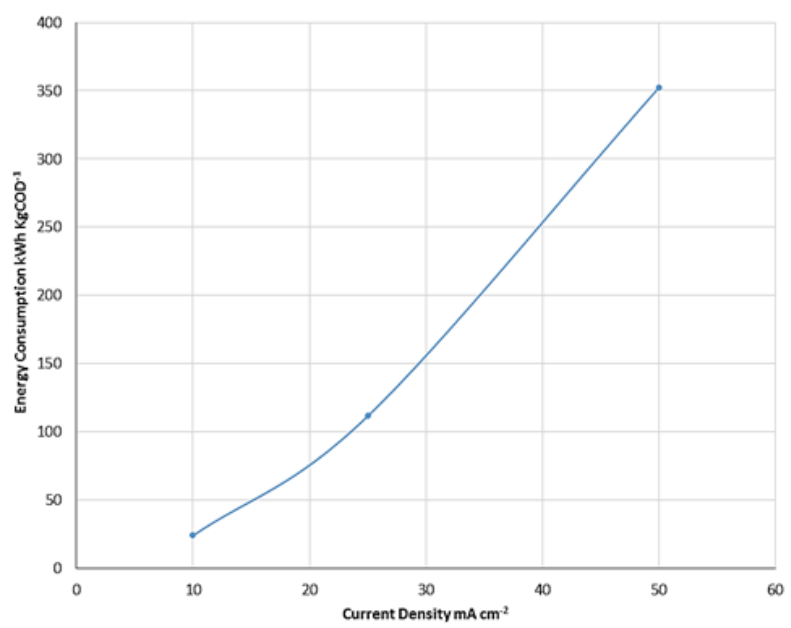

Figure 9. Energy consumption values (kWhkg $\mathrm{COD}^{-1}$ ) according to the current densities

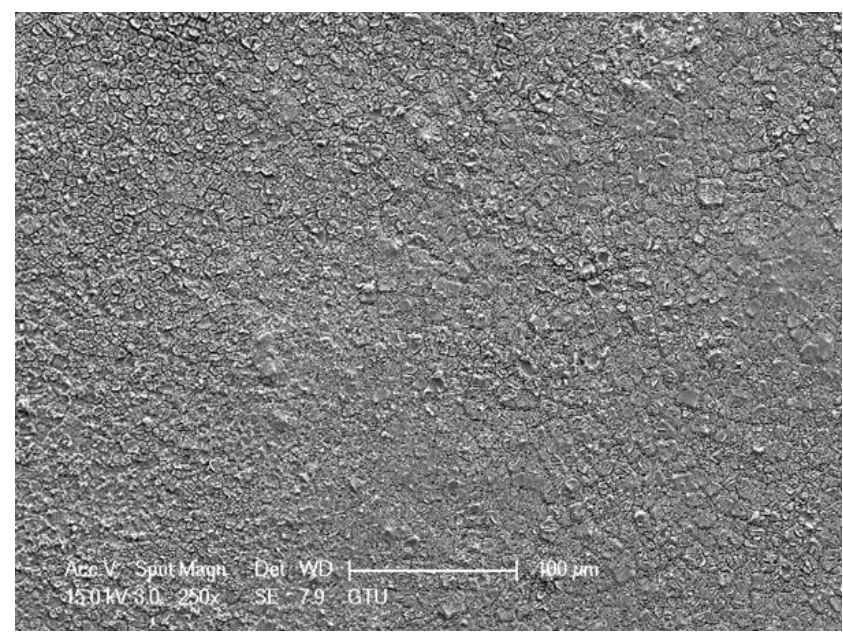

Figure 10. Typical SEM images $(\times 250$, bar $=100 \mu \mathrm{m})$ and EDS spectra of clean (unused) Sn/Sb/Ni: 500:8:1 coated Ti meshes (anodes)

\section{Conclusions}

At this study, electrochemical oxidation of cefaclor antibiotic was investigated using new generation $\mathrm{Sn} / \mathrm{Sb} / \mathrm{Ni}$ $\mathrm{Ti}$ anodes. First of all, in salt addition process, it was obtained that $\mathrm{KCl}$ affected the electrochemical oxidation process efficiencies positively even in lower concenrations. $\mathrm{KCl}$ dose determination studies have shown that; due to the lower voltage, it couldn't obtain higher efficiencies at $500 \mathrm{mg} \mathrm{L}^{-1}$, thus the optimum dose of $\mathrm{KCl}$ was found as 750 $\mathrm{mg} \mathrm{L}^{-1}$ providing the higher removal efficiencies at shorter times. Also, it was seen that, $\mathrm{KCl}$ affected the electrochemical reactions considerably, due to the increase of conductivity and chloride gas formation and thus, hypochlorid acid, according to the kinetic evaluation results.

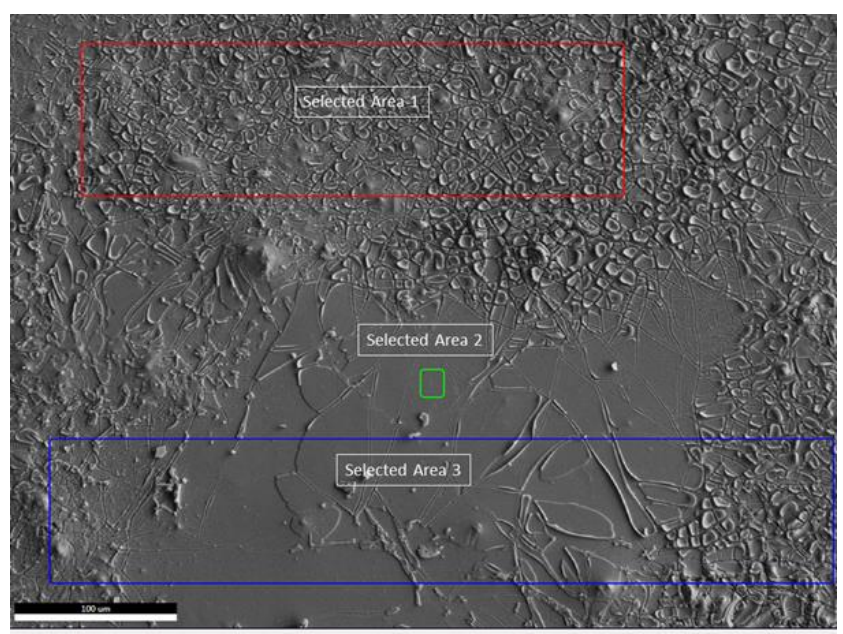

Figure 11. Typical SEM images $(\times 250$, bar $=100 \mu \mathrm{m})$ and EDS spectra of used (unclean) Sn/Sb/Ni: 500:8:1 coated Ti meshes (anodes)

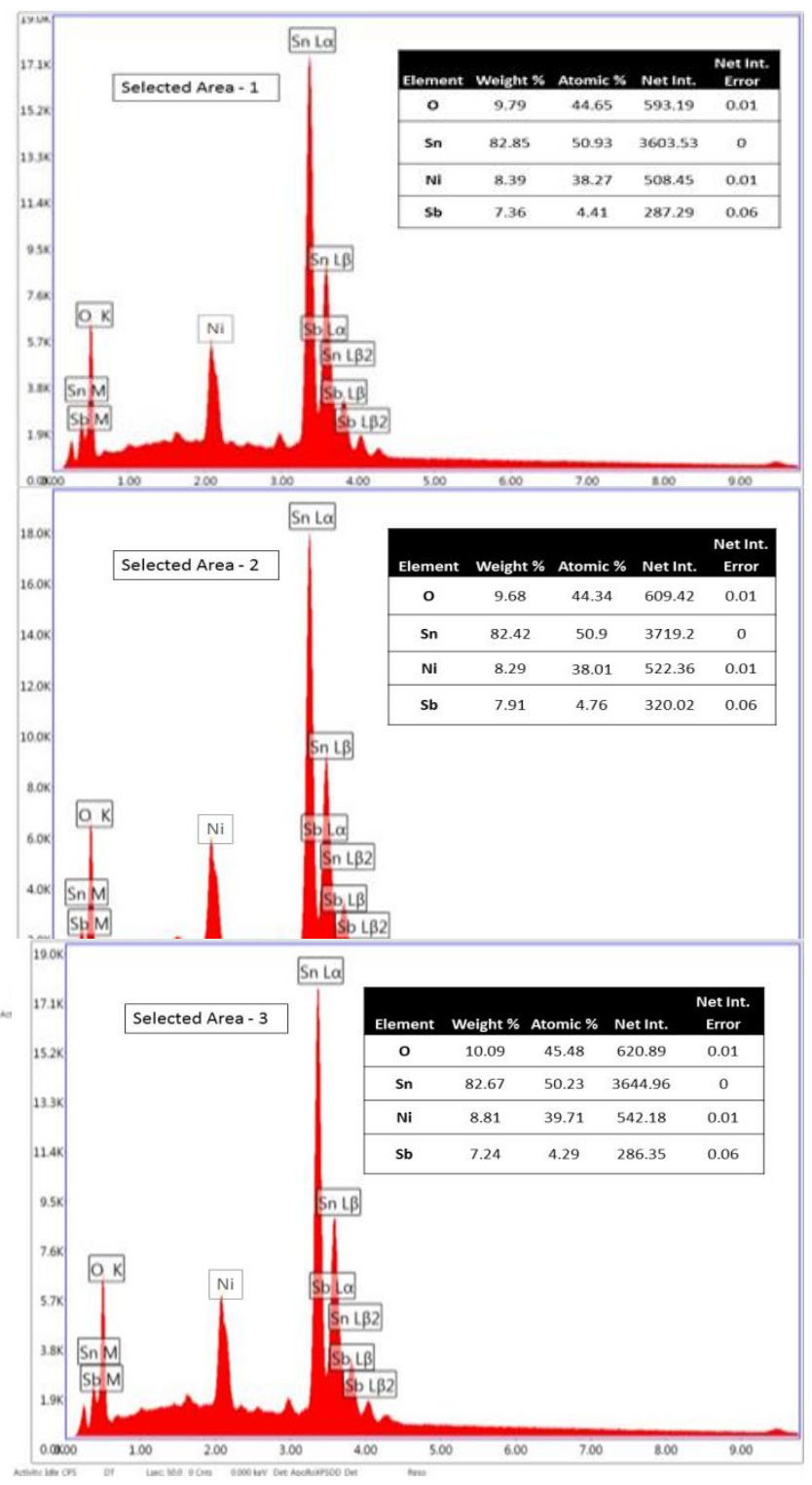

Figure 12. Weight - atomic percentages and the peak intensities of EDS spectra of the anodes 
The $\mathrm{pH}$ value, one of the most important parameter affecting the electrochemical oxidation reactions was investigated and $\mathrm{pH} 7$ was found as the optimum, which is the neutral $\mathrm{pH}$ of the wastewater. Thus, it could possible to make process cheaper and easier operationally, with working at neutral $\mathrm{pH}$ and there is no need extra $\mathrm{pH}$ arrangement steps.

The removal efficiencies increased generally with current density increase, due to active oxidants occur increasingly in aqueous solution at higher current density values. Optimum current density was obtained to be $50 \mathrm{~mA} \mathrm{~cm}^{-2}$, providing the most efficient process. As a result of the SEMEDS analysis, it can be concluded that the anode material was not significantly corroded during the processes and worked efficiently. Consequently, $\mathrm{Sn} / \mathrm{Sb} / \mathrm{Ni}-\mathrm{Ti}$ anodes were found very useful and successful for cefaclor oxidation and mineralization. The advantages of the processes with new generation $\mathrm{Sn} / \mathrm{Sb} / \mathrm{Ni}$-Ti anodes, complete mineralization at shorter reaction time and there is no need to $\mathrm{pH}$ arrangement.

\section{Acknowledgements}

The author acknowledge the support of Bursa Uludag University Research Projects Department for this study (Project No. OUAP (MH)-2018/8).

\section{References}

Abbasi M., Soleymani A.R. and Parssa J.B. (2014), Operation simulation of a recycled electrochemical ozone generator using artificial neural network, Chemical Engineering Research and Design, 92, 2618-2625.

APHA/WEF/AWWA (1989), Standard methods for the examination of water and wastewater, American Public Health Association, 25 Ed., pp. 1-101, Washington DC: Centennial.

Baron S. (1996), Source Medical Microbiology, fourth ed., Galveston (TX), University of Texas Medical Branch at Galveston.

Bergmann M.E.H., Koparal A.S. and lourtchouk T. (2014), Electrochemical Advanced oxidation processes, formation of halogenate and perhalogenate species: A critical review, Critical Reviews in Environmental Science and Technology, 44, 348-390.

Carlos M.H. and Sergio F. (2006), Electrochemical oxidation of organic pollutants for the wastewater treatment: direct and indirect processes, Chemical Society Reviews, 35, 1324-1340.

Christensen P.A., Lin W.F., Christensen H., Imkum A., Jin J.M., Li G. and Dyson C.M. (2009), Room temperature, electrochemical generation of ozone with $50 \%$ current efficiency in $0.5 \mathrm{M}$ sulfuric acid at cell voltages $<3 \mathrm{~V}$, Ozone: Science \& Engineering, 31, 287-293.

Christensen P.A., Zakaria K., Christensen H. and Yonar T. (2013), The effect of $\mathrm{Ni}$ and $\mathrm{Sb}$ oxide precursors, and of $\mathrm{Ni}$ composition, synthesis conditions and operating parameters on the activity, selectivity and durability of $\mathrm{Sb}$-doped $\mathrm{SnO}_{2}$ anodes modified with $\mathrm{Ni}$, Journal of The Electrochemical Society, 160, 405-413.

Comninellis C. and Battisti A.D.E. (1996), Service life of $\mathrm{Ti} / \mathrm{SnO}_{2} \pm$ $\mathrm{Sb}_{2} \mathrm{O}_{5}$ anodes, Journal of Applied Electrochemistry, 27, 970974.
Correa-Lozano B., Comninellis C. and De Battisti A. (1997), Service life of $\mathrm{Ti} / \mathrm{SnO}_{2}-\mathrm{Sb}_{2} \mathrm{O}_{5}$ anodes, Journal of Applied Electrochemistry, 27, 970-974.

Cui Y., Wang Y., Wang B., Haihui Z., Kwong-Yu C. and Xiao-Yan L. (2009), Electrochemical generation of ozone in a membrane electrode assembly cell with convective flow, Science of the Total Environment, 156, E75-E80.

De Moura D.C., de Araújo C.K.C., Zanta C.L.P.S., Salazar R. and Martínez-Huitle C.A. (2014), Active chlorine species electrogenerated on $\mathrm{Ti} / \mathrm{RuO}_{3} \mathrm{TiO}_{7} \mathrm{O}_{2}$ surface: electro-chemical behavior, concentration determination and their application, Journal of Electroanalytical Chemistry, 731, 145-152.

Deng Y. and J.D. Englehardt (2007), Electrochemical oxidation for landfill leachage treatment, Waste Management, 27, 380388.

Gros M., Rodríguez-Mozaz S. and Barceló D. (2013), Rapid analysis of multiclass antibiotic residues and some of their metabolites in hospital, urban wastewater and river water by ultra-highperformance liquid chromatography coupled to quadrupolelinear ion trap tandem mass spectrometry, Journal of Chromatography A, 129, 2173-188.

Harris S.J., Cormican M. and Cummins E. (2012), Antimicrobial residues and antimicrobial-resistant bacteria: Impact on the microbial environment and risk to human health-A review, Human and Ecological Risk Assessment, 18, 767-809.

Joshi S. (2002), HPLC separation of antibiotics present in formulated and unformulated samples, Journal of Pharmaceutical and Biomedical Analysis, 28, 795-809.

Khan S.J. and Ongerth J.E. (2002), Estimation of pharmaceutical residues in primary and secondary sewage sludge based on quantities of use and fugacity modelling, Water Science \& Technology, 46, 105-113.

Khetan S.K. and Collins T.J. (2007), Human pharmaceuticals in the aquatic environment: a challenge to green chemistry, Chemical Reviews, 107, 2319-2364.

Kosutic I., Anderson S.A. and Sabatelli R.M. (2007), Families, urban neighborhood youth centers, and peers as contexts for development, Family Relations, 56, 346-357.

Kurt A. and Yonar T. (2017), Treatability of endocrine disrupting antibiotic compounds by $\mathrm{UV} / \mathrm{H}_{2} \mathrm{O}_{2}$ process according to Taguchi's experimental design, Afyon Kocatepe University Journal of Sciences and Engineering, 17, 854-860.

Kümmerer K. (2009), Antibiotics in the aquatic environment - A review - Part I, Chemosphere, 75, 417-434.

Montilla F., Morallon E., De Battisti A. and Vazquez J.L. (2004), Preparation and characterization of antimony-doped tin dioxide electrodes, Part 1 . Electrochemical characterization, The Journal of Physical Chemistry B, 108, 5036-5043.

Panizza M. and Cerisola G. (2005), Application of diamond electrodes to electrochemical processes, Electrochimica Acta, 51, 191-199.

Park J. (2006), An approach for developing aquatic environmental risk assessment framework for pharmaceu-ticals in Korea. A report from Korea Environment Institute, KEI-RE-05.

Parsa J.B. and Abbasi M. (2012), Application of in situ electrochemically generated ozone for degradation of anthraquninone dye Reactive Blue 19, Journal of Applied Electrochemistry, 42 435-442.

Polcaro A.M., Palmas S., Renoldi F. and Mascia M. (1999), On the performance of $\mathrm{Ti} / \mathrm{SnO}_{2}$ and $\mathrm{Ti} / \mathrm{PbO}_{2}$ anodes in electro- 
chemical degradation of 2-chlorophenol for wastewater treatment, Journal of Applied Electrochemistry, 29, 147-151.

Ribeiro A.R., Sures B. and Schmidt T.C. (2018), Cephalosporin antibiotics in the aquatic environment: A critical review of occurrence, fate, ecotoxicity and removal technologies, Environmental Pollution, 241, 1153-1166.

Samet Y., Elaoud S.C., Ammar S. and Abdelhedi R. (2006), Electrochemical degradation of 4-chloroguaiacol for wastewater treatment using $\mathrm{PbO}_{2}$ anodes, Journal of Hazardous Materials, 138, 614-619.

Sasidharan Pillai I.M. and Gupta A.K. (2016), Anodic oxidation of coke oven wastewater: Multiparameter optimization for simultaneous removal of cyanide, COD and phenol, Journal of Environmental Management, 176, 45-53.

Shekarchizade H. and Amini M.K. (2011), Effect of elemental composition on the structure, electrochemical properties, and ozone production activity of $\mathrm{Ti} / \mathrm{SnO}_{2}-\mathrm{Sb}-\mathrm{Ni}$ Electrodes Prepared by Thermal Pyrolysis Method, International Journal of Electrochemistry, $13 \mathrm{pp}$.

Simond O., Schaller V. and Comninellis C. (1997), Theoretical model for the anodic oxidation of organics on metal oxide electrodes, Electrochimica Acta, 42, 2009-2012.

Stackelberg P.E., Furlong E.T., Meyer M.T., Zaugg S.D., Henderson A.K. and Reissman D.B. (2004), Persistence of pharmaceutical compounds and other organic wastewater contaminants in a conventional drinking-water-treatment plant, Science of the Total Environment, 329, 99-113.

Tchobanoglous G. and Schroeder E.D. (1985), Water Quality: characteristics, modeling, modification, University of Michigan Press, Michigan, 768 pp.

Wang J., Mao D., Mu Q. and Luo Y. (2015), Fate and proliferation of typical antibiotic resistance genes in five full-scale pharmaceutical wastewater treatment plants, Science of the Total Environment, 526, 366-373.

Yao L., Wang Y., Tong L., Li Y., Deng Y., Guo W. and Gan Y. (2015), Seasonal variation of antibiotics concentration in the aquatic environment: A case study at Jianghan Plain, central China, Science of the Total Environment, 527-528, 56-64.

Yonar T. and Kurt A. (2017), Treatability studies of hospital wastewaters with AOPs by Taguchi's experimental design, Globul Nest Journal, 19, 505-510.

Zhou L.J., Ying G.G., Liu S., Zhao J.L., Yang B., Chen Z.F. and Lai H.J. (2013), Occurrence and fate of eleven classes of antibiotics in two typical wastewater treatment plants in South China, Science of the Total Environment, 452-453, 365-376. 